\title{
LEUKOTOXIC ACTIVITY OF ACTINOBACILLUS ACTINOMYCETEMCOMITANS ISOLATED FROM HUMAN AND NON-HUMAN PRIMATES
}

\author{
Francisca Lúcia de Lima ${ }^{1,2}$; Flávio Furtado de Farias ${ }^{2}$; Patrícia Cota Campos²; Antônio Helvécio Totola ${ }^{3}$; Carlos \\ Alberto Pereira Tavares ${ }^{3}$; José Eustáquio da Costa ${ }^{4}$; Luiz de Mácêdo Farias²; Maria Auxiliadora Roque de Carvalho ${ }^{2 *}$ \\ ${ }^{1}$ Centro de Ciências Biológicas e da Saúde, Universidade Estadual do Piauí, Teresina, PI, Brasil. ${ }^{2}$ Departamento de \\ Microbiologia and ${ }^{3}$ Departamento de Bioquímica e Imunologia, Instituto de Ciências Biológicas and ${ }^{4}$ Faculdade de \\ Odontologia, Universidade Federal de Minas Gerais, Belo Horizonte, MG, Brasil
}

Submitted: December 13, 2000; Returned to authors for corrections: May 12, 2001; Approved: July 23, 2001

\begin{abstract}
Actinobacillus actinomycetemcomitans is a clinically relevant periodontopathogenic Gram-negative coccobacillus that produces a leukotoxin of the RTX cytolysin family. In this study, we evaluated the leukotoxic activity of $A$. actinomycetemcomitans strains isolated from human and marmosets by Trypan blue exclusion and by the chemiluminescence assays. Among eight $A$. actinomycetemcomitans human strains studied, two $\left(\mathrm{P}_{2.17}\right.$ and $\left.\mathrm{P}_{8.12}\right)$ were classified as high leukotoxin producers and among eight marmoset strains, one $\left(\mathrm{M}_{22.11}\right)$ showed high leukotoxin production, as determined by Trypan blue exclusion assay. The reference strains ATCC 29523 and FDC Y4 respectively behaved like moderate and low producers. The chemiluminescence assay was used to evaluate the leukotoxic activity of $\mathrm{M}_{22.11}$ and $\mathrm{P}_{2.17}$ strains submitted to different growth conditions. Leukotoxic activity was detected on cells at the logarithmic phase and was similar under anaerobic and microaerophilic growth conditions. It was greatly reduced when cells were grown at glucose concentrations lower or higher than $0.75 \%(0.25 \%$ and $1.5 \%)$ in thioglycolate medium. Leukotoxin production mainly by the $\mathrm{M}_{22.11}$ strain was low in BHI broth, whereas production in TSB medium showed a similar level as in thioglycolate broth medium. Sodium bicarbonate at $10 \mathrm{mM}$ did not affect leukotoxin production.
\end{abstract}

Key words: Actinobacillus actinomycetemcomitans, periodontopathogen, leukotoxic activity, chemiluminescence assay

\section{INTRODUCTION}

Actinobacillus actinomycetemcomitans is a capnophilic Gram-negative coccobacillus related to periodontal disease, especially localized juvenile periodontitis, of considerable importance in both human and veterinary medicine $(18,23,26)$. This organism has been associated to a variety of other infectious diseases such us endocarditis, brain abscesses, osteomyelitis and subcutaneous abscesses (26). Although a number of potential virulence factors from $A$. actinomycetemcomitans have been described $(5,24)$, the best characterized is a heat-labile exotoxin that rapidly destroys human polymorphonuclear leukocytes (PMNs), monocytes, natural killer cells, T lymphocytes, and monkey polymorphonuclear leukocytes $(12,14)$.

Molecular genetic analysis have indicated that the $A$. actinomycetemcomitans leukotoxin is a member of the RTX (repeats in toxin) family including the Escherichia coli alphahemolysin and the Pasteurella haemolytica leukotoxin $(9,10)$. In the RTX toxin determinants, genes for toxin synthesis, activation, and secretion are grouped together on the chromosome in an operon named ltx (10). Although the ltx operon seems to be present in all A. actinomycetemcomitans strains, the levels of toxin expression vary considerably among different strains (8). High levels of leukotoxin expression appear to be

\footnotetext{
* Corresponding author. Mailing address: Departamento de Microbiologia, Instituto de Ciências Biológicas, UFMG, Av. Antônio Carlos, 6627, Pampulha. 31270-901, Belo Horizonte, Minas Gerais, Brasil. Tel: (+5531) 499-2743, Fax: (+5531) 449-2730. E-mail: marc@mono.icb.ufmg.br
} 
related to the presence of the JP2-like promoter (530 bp deletion), although physiological factors may be involved in this regulation $(8,13,16,20)$.

Several methods has been proposed to obtain and evaluate the leukotoxic activity in different sensibility levels $(2,24)$. The chemiluminescence inhibition assay has been used to determine the leucotoxic activity on PMNs in various studies $(3,6,17)$, and is a very sensitive assay of cells functional ability (2). However it has not been used to evaluated the leukotoxic activity of $A$. actinomycetemcomitans. Studies using isolates from different geographical populations are lacking. In the present investigation, we compare the leukotoxic activity of several $A$. actinomycetemcomitans strains isolated from human and nonhuman primates by the Trypan blue exclusion assay. The effects of environmental conditions on the leukotoxic activity of two A. actinomycetemcomitans strains were evaluated by the chemiluminescence assay.

\section{MATERIALS AND METHODS}

\section{Bacterial strains and culture conditions}

Reference strains A. actinomycetemcomitans FDC Y4 (Forsyth Dental Center, Boston, Massachusetts, USA), ATCC 29523 (American Type Culture Collection, Rockville, Maryland, USA), and 16 strains from our culture collection isolated from human beings (progressive rapid periodontitis $-\mathrm{P}_{2.2}, \mathrm{P}_{2.17}, \mathrm{P}_{7.13}, \mathrm{~B}_{4}, \mathrm{~L}_{2}$-, adult periodontitis $-\mathrm{P}_{11.18}$ and $\mathrm{P}_{14.21}$-, and healthy periodontum $\mathrm{P}_{8.12}$ ) and from marmosets (gingivitis $-\mathrm{M}_{20.1}, \mathrm{M}_{20.15}, \mathrm{M}_{20.25}, \mathrm{M}_{16.2}$, $\mathrm{M}_{28.8}, \mathrm{M}_{38.7}-$, and healthy periodontum $-\mathrm{M}_{22.11}$ and $\mathrm{M}_{22.19}$ ) were used. The organisms were grown in modified thioglycolate broth medium (21) supplemented with $0.5 \%$ yeast extract (Difco), and incubated in an anaerobic chamber $\left(85 \% \mathrm{~N}_{2}, 10 \% \mathrm{H}_{2}\right.$, and $5 \%$ $\mathrm{CO}_{2}$ ). Routinely, $950 \mathrm{~mL}$ of thioglycolate medium were inoculated with $50 \mathrm{~mL}$ of a 24 hour culture of $A$. actinomycetemcomitans and incubated for 48 hours, at $37^{\circ} \mathrm{C}$, in an anaerobic chamber.

\section{Recovery of extracts for trypan blue exclusion assays}

Extracts from whole cells were obtained as previously described (14). Actinobacillus actinomycetemcomitans cells were washed twice $\left(16,000 \mathrm{xg}\right.$ for $20 \mathrm{~min}$. at $\left.4^{\circ} \mathrm{C}\right)$ in phosphate buffered saline - PBS ( $0.68 \%$ (w/v), NaCl, $0.12 \%$ (w/v) $\mathrm{Na}_{2} \mathrm{HPO}_{4}, 0.07 \%$ (w/ v) $\mathrm{KH}_{2} \mathrm{PO}_{4} ; \mathrm{pH} 7.0$ ), and resuspended in $20 \mathrm{~mL}$ of PBS. The suspension was submitted to sonication, in ice-water bath, at 16 $\mathrm{KHz}$ in a $200 \mathrm{~W}$ ultrasonic disrupter (Branson 450 - Model MSE), and centrifuged as above. The supernatants were concentrated as described by Ohta et al. (15). Ammonium sulfate was added to $50 \%$ saturation on ice (C-50 fraction), and the precipitate was collected by centrifugation $\left(25,000 \mathrm{xg}\right.$ for $25 \mathrm{~min}$. at $\left.4^{\circ} \mathrm{C}\right)$. The supernatant was resaturated with $70 \%$ ammonium sulfate, resulting in the C-70 fraction. Both precipitates were resuspended in $5 \mathrm{~mL}$ PBS and dialyzed against $0.05 \mathrm{M}$ ammonium bicarbonate buffer; $\mathrm{pH} 7.2$ (1/200 of the suspension volume) overnight, followed by lyophilization and storage at $-86^{\circ} \mathrm{C}$. Protein content was determined by the method of Lowry et al. (11).

\section{Recovery of sonic extracts for the chemiluminescence assays}

For the chemiluminescence assays, sonic extracts obtained from 24 hours culture of $A$. actinomycetemcomitans $\mathrm{M}_{22.11}$ and $\mathrm{P}_{2.17}$ strains were precipitated with $40 \%$ (C-40 fraction) and $80 \%$ (C-80 fraction) ammonium sulfate and dialyzed against ammonium bicarbonate buffer. These extracts were not lyophilized. The cells were submitted to different growth conditions using thioglycolate medium as follows: (1) glucose concentration $-0.25 \%, 0.75 \%$ and $1.50 \%$; (2) adittion of sodium bicarbonate - $10 \mathrm{mM}$; (3) atmosphere of incubation anaerobiosis and microaerophilia; the culture media Brain Heart Infusion (BHI; Difco) and Tryptic Soy Broth (TSB; Difco) were also employed. Leukotoxic activity of sonic extracts from cells in each condition, as well from at different growth curve phases (midlog, later log and stationary) were evaluated.

\section{Isolation of human polymorphonuclear cells}

Polymorphonuclear leukocytes (PMNs) from adult donors (not pooled) were isolated from heparinized venous blood by centrifugation on Ficoll Hypaque gradients as described by Bicalho et al. (1). The PMNs were resuspended in RPMI 1640 medium (Trypan blue exclusion test) or in veronal buffer (chemiluminescence assay) (4). PMNs donors were adult (2030 years old) from both gender, and had no relevant history of periodontal disease.

\section{Assay of PMNs viability by Trypan blue exclusion}

After exposure of $10^{6} \mathrm{PMNs}$ to $100 \mu \mathrm{L}$ of protein extracts (500 $\mu \mathrm{g} / \mathrm{mL}$ ), from every strains, in a final volume of $600 \mu \mathrm{L}$, for $60 \mathrm{~min}$., a Trypan blue suspension $(1.6 \mathrm{mg} / \mathrm{mL}$ in saline solution) was added to the PMNs monolayers at a final concentration of 0.8 $\mathrm{mg} / \mathrm{mL}$ (14). The monolayers were kept at $37^{\circ} \mathrm{C}$ for $7 \mathrm{~min}$. in a $\mathrm{CO}_{2}$ chamber (5\%), mounted on a hemocytometer and then observed under light microscope. The cells taking up Trypan blue (dead cells), and cells excluding the dye (viable cells) were counted.

\section{Decrease of PMNs viability caused by leucotoxic activity}

A cell death curve was determined by the Trypan blue exclusion test. PMNs $\left(2 \times 10^{6}\right.$ cells $\left./ \mathrm{mL}\right)$ were incubated with 200 $\mu \mathrm{L}$ of protein extract $\left(250 \mu \mathrm{g} / \mathrm{mL}\right.$ - C-70 fraction; from $\left.\mathrm{M}_{20.19}\right)$ at $37^{\circ} \mathrm{C}$, in $5 \% \mathrm{CO}_{2}$, in a final volume of $600 \mu \mathrm{L}$. After intervals of 0 , $10,20,30,40,45,60,90$ and 120 min., aliquots were taken $(20 \mu \mathrm{L})$ and assayed for PMNs viability.

\section{Chemiluminescence assay}

Leukotoxic activity was measured by chemiluminescence (4, 6). PMNs $\left(10^{6}\right)$, suspended in $200 \mu \mathrm{L}$ veronal buffer, were stimulated with the addition of tetradecanoyl-phorbol-acetate (TPA; $0.005 \mu \mathrm{g})$ in the presence of luminol $\left(10^{-5} \mathrm{M}\right)$ in a final 
volume of $750 \mu \mathrm{L}$ in PBS; $\mathrm{pH}$ 7.2. The chemiluminescence emission was measured in millivolts $(\mathrm{mV})$ at 1 sintervals at room temperature using a Wallac luminometer (LBK Wallac 1250). A ideal dose was determined by addition of different doses of protein extracts. For the routine chemiluminescence assays, $50 \mu \mathrm{L}$ of protein extract $\left(250 \mu \mathrm{g} / \mathrm{mL} ; \mathrm{M}_{22.11}\right.$ and $\left.\mathrm{P}_{2.17}\right)$ were added to PMNs suspension and incubated for $10 \mathrm{~min}$. at room temperature, and the light emission was measured as above. Leukotoxic activity was expressed as percentage of inhibition of the peak value of the normal chemiluminescence response (control) of the PMNs to TPA. Negative controls were performed without addition of TPA.

\section{Proteic nature determination}

As we worked with crude extracts, $200 \mu \mathrm{L}$ of each one was submitted to different treatments for the determination of its proteic nature: (1) $70^{\circ} \mathrm{C}$, for $30 \mathrm{~min}$.; (2) $100^{\circ} \mathrm{C}$, for $10 \mathrm{~min}$.; and (3) trypsin $10 \mu \mathrm{L}(1 \mathrm{mg} / \mathrm{mL})$, for $30 \mathrm{~min}$. Leukotoxic activities were verified by chemiluminescence assays.

\section{RESULTS}

\section{Effect of the $A$. actinomycetemcomitans protein extracts on PMNs}

In serum-free cultures, eighteen strains of A. actinomycetemcomitans from human and non-human primates showed leukotoxic activity as indicated by the Trypan blue exclusion test (Table 1). Sonic extracts that killed less than $40 \%, 40$ to $70 \%$ and $70 \%$ or more PMNs were considered to be low, medium and high-producers, respectively. The viability of PMNs in controls was $98.00 \%$ with human strains and $97.00 \%$ for marmoset ones. According to the Table 1, the highest leukotoxic activity was detected on C-70 fractions. The FDC Y4 strain was considered to be a medium producer inducing $54 \%$ cell death, whereas the extract from ATCC 29523 induced $34 \%$ cell death, regarding the C-70 fractions. Among human strains, 6 were medium and 2 high producers, whereas 1, 6 and 1 marmoset strains were low, moderate and high producers, respectively. Among marmoset strains, the highest and lowest leukotoxin producers were isolated from the same animal.

The decrease of PMNs viability occurred at a higher rate during the initial $20 \mathrm{~min}$. of incubation with the protein extract from A. actinomycetemcomitans $\mathrm{M}_{20.19}$ strain than later on (final concentration - $83.3 \mu \mathrm{g} / \mathrm{mL}$ ).

\section{Quantitative analysis of PMNs sensitivity to $A$. actinomycetemcomitans leukotoxin}

Leukotoxin caused a dose-dependent inhibition of the chemiluminescence of PMNs. The highest dose of sonic extract which gave a chemiluminescence reading was $62.5 \mu \mathrm{g} / \mathrm{mL}$ and the lethal average dose $\left(\mathrm{LD}_{50}\right)$, i.e., the dose of $\mathrm{C}-80$ extract required to inhibit $50 \%$ of chemiluminescence response of PMNs, was calculated to be approximately $0.02 \mu \mathrm{g} / \mathrm{mL}$ (Fig. 1).
Table 1. Leukotoxic activity of Actinobacillus actinomycetemcomitans strains isolated from the human and marmoset oral cavity.

\begin{tabular}{ccc}
\hline & \multicolumn{2}{c}{$\%$ of inhibition } \\
\cline { 2 - 3 } Strains & $\begin{array}{c}\text { C-50 sonic } \\
\text { extract }\end{array}$ & $\begin{array}{c}\text { C-70 sonic } \\
\text { extract }\end{array}$ \\
\hline Reference strains & & \\
ATCC 29523 & 6.3 & 34.0 \\
FDC Y4 & 41.0 & 54.0 \\
$\mathrm{P}_{2.2}$ & 59.0 & 65.3 \\
$\mathrm{P}_{2.17}$ & 73.0 & 82.0 \\
$\mathrm{P}_{7.13}$ & 27.3 & 48.7 \\
$\mathrm{P}_{8.12}$ & 56.3 & 73.3 \\
$\mathrm{P}_{11.18}$ & 47.7 & 68.4 \\
$\mathrm{P}_{14.21}$ & 27.4 & 41.2 \\
$\mathrm{~B}_{4}$ & 29.6 & 63.4 \\
$\mathrm{~L}_{2}$ & 33.0 & 58.4 \\
& & \\
$\mathrm{M}_{20.1} *$ & 33.6 & 48.5 \\
$\mathrm{M}_{20.19} *$ & 43.1 & 68.4 \\
$\mathrm{M}_{20.25^{*}}$ & 38.9 & 50.0 \\
$\mathrm{M}_{22.11} *$ & 58.2 & 90.5 \\
$\mathrm{M}_{22.19^{*}}$ & 19.2 & 28.5 \\
$\mathrm{M}_{16.2}{ }^{*}$ & 35.3 & 53.0 \\
$\mathrm{M}_{38.8}{ }^{\dagger}$ & 39.7 & 59.6 \\
$\mathrm{M}_{38.3}{ }^{*}$ & 12.2 & 46.0 \\
\hline
\end{tabular}

* Callithrix jacchus; $\dagger$ Callithrix geoffroy; $\$$ Callithrix penicillata.

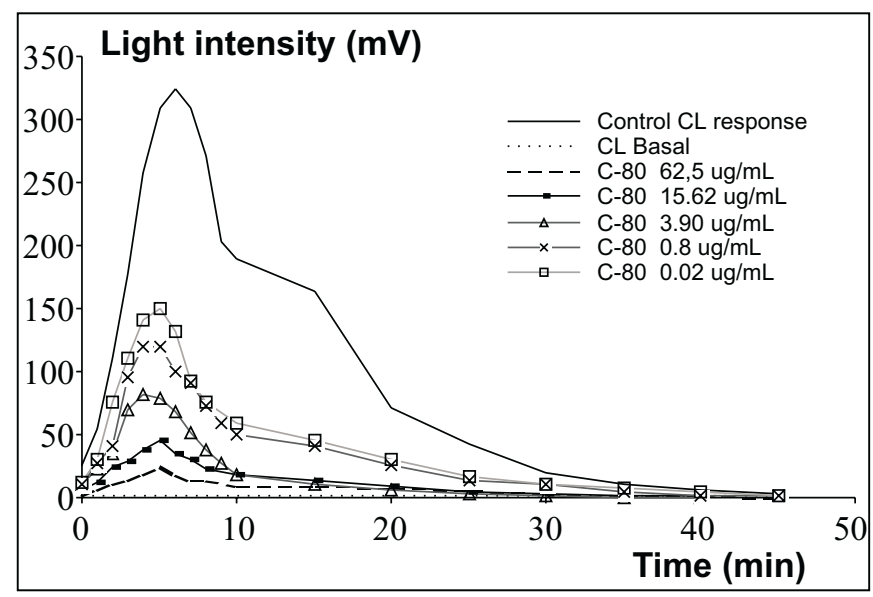

Figure1. The effect of different concentrations of $A$. actinomycetemcomitans $\mathrm{C}-80$ sonic extract on peripheral blood mononuclear cells. Several dilutions of a sonic extract from the $\mathrm{P}_{2.17}$ strain were added to human PMNs $\left(10^{6}\right.$ cells $)$ and the effect was measured by chemiluminescence for $45 \mathrm{~min}$. Control cells were incubated with TPA. 


\section{Chemiluminescence inhibition by sonic extracts of $A$. actinomycetemcomitans strains $\mathbf{P}_{2.17}$ and $\mathbf{M}_{22.11}$}

Results of a chemiluminescence inhibition assay with human neutrophils and samples from two strains of $A$. actinomycetemcomitans are shown in Fig. 2

Sonic extracts from strains $\mathrm{M}_{22.11}$ and $\mathrm{P}_{2.17}$ were highly toxic for human PMNs. Leukotoxic activity was detected within 6 hours of growth (midlog phase) and no significant additional increase was observed after 12 and 24 hours (data not shown). The atmosphere of incubation and the addition of sodium bicarbonate at $10 \mathrm{mM}$ did not affect the toxicity of sonic extracts from both strains. The leukotoxic activity was intensely reduced by lower glucose concentration $(0.25 \%$ glucose $)$ in both $\mathrm{P}_{2.17}$ and $\mathrm{M}_{22.11}$ strains (only $10.46 \%$ and $3.76 \%$ chemiluminescence inhibition, respectively). A higher glucose concentration $(1.5 \%$ glucose) also reduced the chemiluminescence response (58.51\% for $\mathrm{P}_{2.17}$ and $68.11 \%$ for $\mathrm{M}_{22.11}$, respectively), whereas in the presence of $0.75 \%$ glucose, the chemiluminescence response was inhibited by $92.75 \%$ and $93.74 \%$, respectively (Fig. 3). When the leukotoxic activity of the two A. actinomycetemcomitans strains grown in different culture media was compared, higher activities were observed when the cells were cultivated in tioglycolate and TSB media (93.50\% and $90.03 \%$ inhibition for $\mathrm{M}_{22.11}$ strain and 92.48 and 92.82 for $\mathrm{P}_{2.17}$ strain, respectively) than in BHI media (72.04\% inhibition for the $\mathrm{M}_{22.11}$ strain and $90.28 \%$ inhibition for the $P_{2.17}$ strain). Fig. 4 shows extract activity from $\mathrm{M}_{22.11}$ strain.

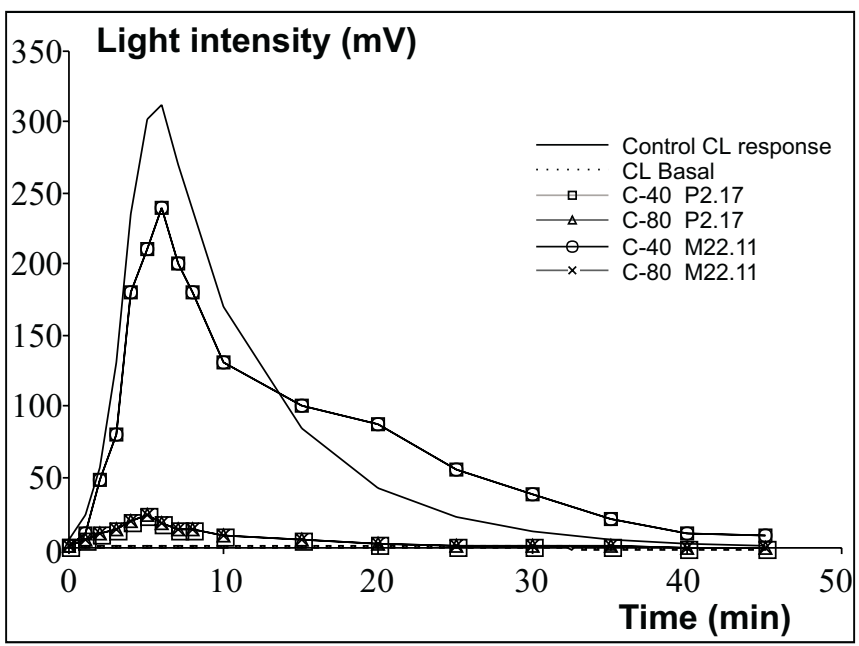

Figure 2. The effect of a sonic extract C-40 and C-80 from $A$. actinomycetemcomitans $\mathrm{P}_{2.17}$ and $\mathrm{M}_{22.11}$ strains on the chemiluminescence response of human PMNs to TPA. The inhibition curves of both strains for the C-40 and C-80 fractions, were the same. The sonic extracts were obtained from an anaerobic growth at $37^{\circ} \mathrm{C}$ for 24 hours. Human PMNs $\left(10^{6}\right.$ cells $)$ were incubated with $50 \mathrm{~mL}$ sonic extracts $(0.5 \mathrm{mg} / \mathrm{mL})$.

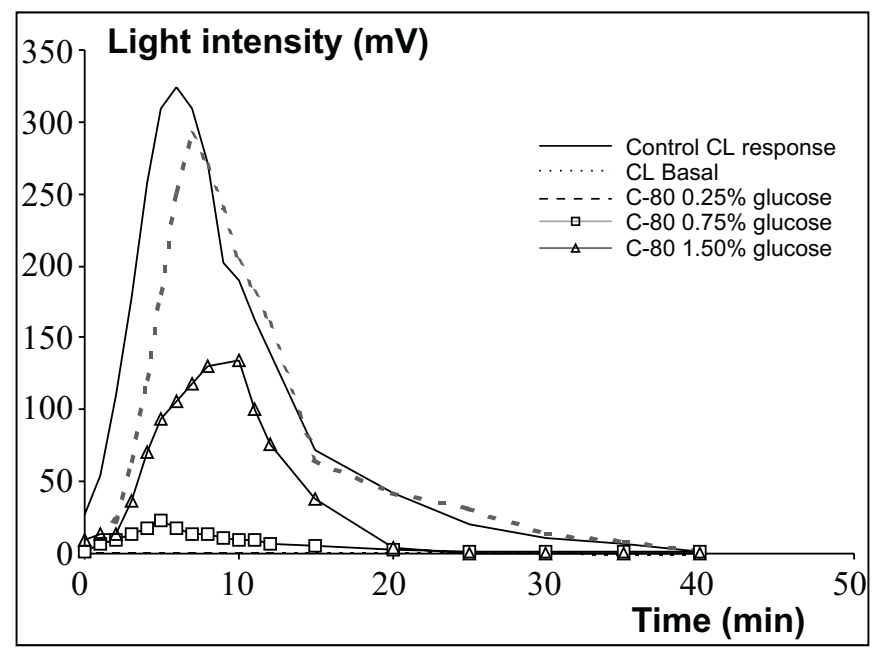

Figure 3. The effect of a sonic extract (C-80 fraction) from $A$. actinomycetemcomitans $\mathrm{P}_{2.17}$ strain grown at different concentrations of glucose on the chemiluminescence response of human PMNs to TPA. The sonic extracts were obtained from an anaerobic growth at $37^{\circ} \mathrm{C}$ for 24 hours. Human PMNs $\left(10^{6}\right.$ cells) were incubated with $50 \mu \mathrm{L}$ sonic extracts $(0.5 \mathrm{mg} / \mathrm{mL})$.

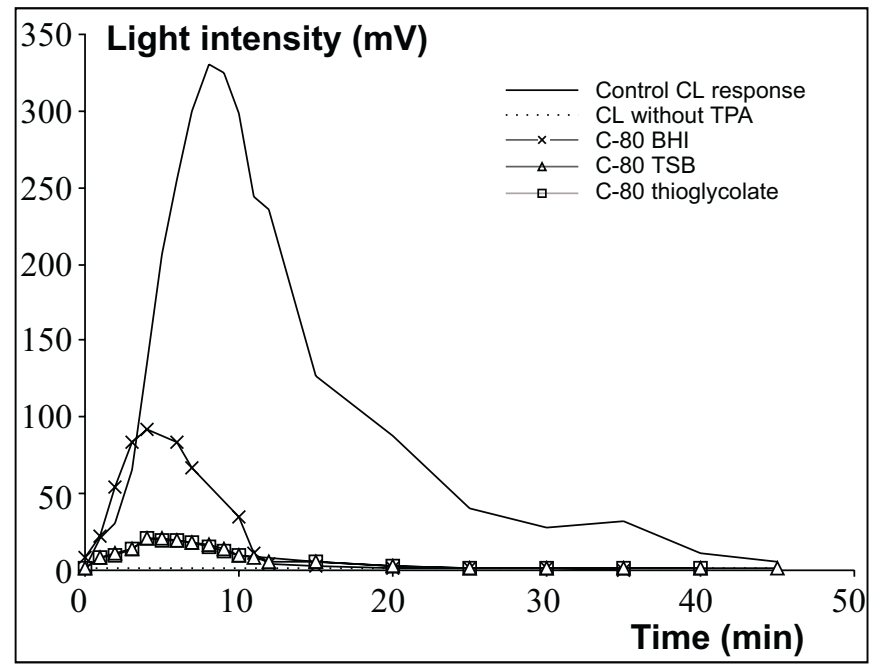

Figure 4. The effect of a sonic extract (C-80 fraction) from $A$. actinomycetemcomitans $\mathrm{M}_{22.11}$ strain grown in different culture media on the chemiluminescence response of human PMNs to TPA. The sonic extracts were obtained from an anaerobic growth at $37^{\circ} \mathrm{C}$ for 24 hours. Human PMNs $\left(10^{6}\right.$ cells $)$ were incubated with $50 \mu \mathrm{L}$ sonic extracts $(0.5 \mathrm{mg} / \mathrm{mL})$.

\section{Proteic nature determination}

Incubation at $70^{\circ} \mathrm{C}$ for $30 \mathrm{~min}$. or boiling in water for $10 \mathrm{~min}$., as also the treatment for $30 \mathrm{~min}$. at room temperature with trypsin $10 \mu \mathrm{L}(1 \mathrm{mg} / \mathrm{mL})$ completely inactivated the leukotoxin. This 
indicates that the molecules presenting leukotoxic activity have a proteic nature.

\section{DISCUSSION}

The present study was designed to investigate the leukotoxic activity of $A$. actinomycetemcomitans isolated from 7 human subjects and from 5 marmosets in Brazil, to evaluate its heterogeneity and to examine the environmental effects on this activity. Marmoset strains were included because wild primate populations may hold valuable clues to the origins and evolution of some important pathogens (28).

Although initial observations have demonstrated a strong association between high leukotoxic activity strains and periodontal disease (29), as well as high leukotoxin producer strains and younger patients (26), more recent findings suggest that highly leukotoxic strains may only be important in the pathogenesis activity, although in our study this activity was extremely heterogeneous. Interestingly, the higher and lower leukotoxin producer strains were isolated from the same animal. Moreover, the strain $\mathrm{P}_{8.12}$ was a high producer (73.3\%) despite its healthy subject origin, and the strains from periodontal disease patients were moderate producers.

The kinetics of leukotoxic activity is similar to that reported in others studies $(12,23)$. The maximal activity occurred after 60 min. of PMNs incubation with sonic extracts (C-70 fraction) of the $A$. actinomycetemcomitans $\mathrm{M}_{20.19}$ strain, although the highest rate of activity was observed during the initial $20 \mathrm{~min}$.

Chemiluminescence was used in this study to evaluate the leukotoxic potential of $\mathrm{M}_{22.11}$ and $\mathrm{P}_{2.17}$ strains submitted to different growth conditions. Initially, the protein concentration was standardized. The ideal dose was $62.5 \mu \mathrm{g} / \mathrm{mL}$, because higher concentrations completely inhibited the chemiluminescence response. On the other hand, a lower concentration could be confused with the decrease in leukotoxic activity (Data not shown). The lethal average dose $\left(\mathrm{LD}_{50}\right)$ was approximately 0.02 $\mathrm{mg} / \mathrm{mL}$ (46.36\% inhibition), a concentration lower than that reported by Taichman et al. (24) who found $0.37 \mu \mathrm{g} / \mathrm{mL}$ to be the $\mathrm{LD}_{50}$ on PMNs for A. actinomycetemcomitans JP2 strain, a high leukotoxin producer. These differences could be due to methodological approaches used in each study.

Ohta et al. (14) reported leukotoxic activity of sonic extract obtained during the stationary phase, but no activity of extracts obtained during the exponential growth phase. In contrast, in this study leukotoxic activity was evidenced after 6 hours of growth (mid-exponential growth phase) for both strains, and no significant additional increase was observed during the later exponential phase or during the stationary phase. This data agrees with results obtained by Spitznagel et al. (20) who observed that the ltxA and $l x B$ transcripts increased during the logarithmic growth phase and decreased as the cell entered the stationary phase.
Hritz et al. (8) reported that the production of leukotoxin is repressed by aeration, and this oxygen-dependent regulation differs significantly between highly toxic and minimally toxic $A$. actinomycetemcomitans strains (JP2 and 652, respectively), resulting in different levels of leukotoxic protein production rather than a change in toxin activity (21). In our study, the $\mathrm{M}_{22.11}$ and $\mathrm{P}_{2.17}$ strains were not influenced by aeration, i.e., they behaved similarly to JP2 strain.

Little is known about the physiological basis of the leukotoxic activity. Ohta et al. (17) have studied the effects of bicarbonate concentration and fermentable sugar levels in a chemostat culture on the production of leukotoxin by $A$. actinomycetemcomitans. The addition of $10 \mathrm{mM}$ bicarbonate stimulated the efficiency of leukotoxin synthesis up to about threefold, whereas a further increase of bicarbonate concentration $(20-40 \mathrm{mM})$ had no effect on total leukotoxin production, but increased the amount of leukotoxin in the supernatants (17). Our findings do not confirm these results since no differences in leukotoxic activity were observed among the $\mathrm{M}_{22.11}$ and $\mathrm{P}_{2.17}$ strains when bicarbonate was added to a final concentration of $10 \mathrm{mM}$, in tioglycolate medium.

Mizoguchi et al. (13) demonstrated that leukotoxin production is repressed by fructose and glucose in chemostat cultures, but not by a non-fermentable sugar analog. Our results revealed that higher and lower glucose concentrations $(1.50 \%$ and $0.25 \%$ ) had a negative effect on leukotoxin production when compared with $0.75 \%$ glucose concentration in thioglycolate medium. Interestingly, sonic extracts from both strains growing in different culture media presented varied leukotoxic activity levels. The cells growing in BHI showed the lowest leukotoxin production whereas the cells grown in both TSB and thioglycolate broth medium showed the highest leukotoxin production. These differences should be related to the glucose and protein concentration of the different culture media employed. Curiously, despite the low glucose concentration in BHI broth $(<0.02 \%)$, leukotoxic activity was higher than in thioglycolate at $0.25 \%$ glucose concentration. We hypothesize that protein contents in $\mathrm{BHI}(>90 \%)$, as well as in TSB containing $0.25 \%$ glucose and approximately $60 \%$ protein, might have stimulated leukotoxin production.

In summary, the diversity of leukotoxin expression by $A$. actinomycetemcomitans strains suggests the need of detecting new parameters for a better evaluation of the role of leukotoxin in periodontal and other infectious diseases.

\section{ACKNOWLEDGMENTS}

We thank Mr. Jamil Silvano de Oliveira, Mr. Francisco José Santos Neves Júnior and Mrs. Luzia Rosa Rezende for excellent technical assistance. The authors are indebted to Dr. Maria Carla Bastos Abdo and Dr. Paula Prazeres Magalhães for their cooperation. 
This work was supported by Conselho Nacional de Desenvolvimento Científico e Tecnológico (CNPq), Fundação de Amparo à Pesquisa de Minas Gerais (FAPEMIG), PróReitoria de Pesquisa da Universidade Federal Minas Gerais, Brazil. Francisca Lúcia de Lima was supported by grant of Coordenadoria de Aperfeiçoamento de Professores do Ensino Superior (CAPES) and Universidade Estadual do Piauí.

\section{RESUMO}

\section{Atividade leucotóxica de amostras de Actinobacillus actinomycetemcomitans de primatas humanos não-humanos}

Actinobacillus actinomycetemcomitans é um cocobacilo Gram negativo, periodontopatógeno clinicamente importante, que produz uma leucotoxina pertencente à família das citolisinas RTX. Neste estudo, avaliou-se a atividade leucotóxica de amostras de A. actinomycetemcomitans isoladas de seres humanos e de calitriquídeos pelos métodos de exclusão de azul de Tripan e quimioluminescência. Duas $\left(\mathrm{P}_{2.17}\right.$ e $\left.\mathrm{P}_{8.12}\right)$ entre oito amostras de $A$. actinomycetemcomitans isoladas de seres humanos, e uma $\left(\mathrm{M}_{22.11}\right)$ entre 8 amostras isoladas de sagüis se apresentaram como altamente produtoras de leucotoxina, como determinado pelo teste de exclusão de azul de Tripan. As amostras de referências de A. actinomycetemcomitans ATCC 29523 e FDC Y4 se comportaram como média e baixa produtoras de leucotoxina, respectivamente. $\mathrm{O}$ teste de quimioluminescência foi usado para avaliar a atividade leucotóxica das amostras $\mathrm{M}_{22.11}$ e $\mathrm{P}_{2.17}$ submetidas a diferentes condições de crescimento. A atividade leucotóxica foi detectada em células durante a fase logarítmica e foi similar sob crescimento em anaerobiose e microaerofilia. A atividade leucotóxica foi muito reduzida quando as células foram crescidas em concentrações de glicose mais baixa e mais alta que $0,75 \%(0,25 \%$ e $1,5 \%)$, em meio tioglicolato. A produção de leucotoxina, especialmente pela amostra $\mathrm{M}_{22.11}$, foi mais baixa em caldo BHI, enquanto em meio TSB a produção foi em nível similar a aquele em meio tioglicolato. Bicarbonato de sódio $10 \mathrm{mM}$ não afetou a produção de leucotoxina.

Palavras-chave: Actinobacillus actinomycetemcomitans; periodontopatógeno; atividade eucotóxica; ensaio de quimioluminescência

\section{REFERENCES}

1. Bicalho, H.M.; Gontijo, C.M.; Nogueira-Machado, J.A. A simple technique for simultaneous human leukocyte separation. J. Immunol. Methots., 40:115-116, 1981.

2. Chang, Y.F.; Renshaw, H.W. Pasteurella haemolytica leukotoxin comparison of 51chromium-release, trypan blue dye exclusion, and luminol-dependent chemiluminescence-inhibition assays for sensitivity in detecting leukotoxin. Am. J. Vet. Res., 47:134-138, 1986.
3. Czuprynski, C.J.; Noel, E.J. Influence of Pasteurella haemolytica A1 crude leukotoxin on bovine neutrophil chemiluminescence. Infect. Immun., 58:1485-1487, 1990

4. Eisemann, K.; Totola, A.; Jurcic, K.; Pettit, G.R.; Wagner, H. Bryostatins 1, 2 and 5 activate human granulocytes and lymphocytes: in vitro and in vivo studies. Pharm. Pharmacol. Lett., 1:45-48, 1995.

5. Fives-Taylor, P.M.; Meyer, D.H.; Mintz, K.P.; Brissette, C. Virulence factors of Actinobacillus actinomycetemcomitans. Periodontology 2000, 20:136-167,1999.

6. Gomez, R.S.; Costa, J.E.; Lorentz, T.M.; Garrocho, A.A.; NogueiraMachado J.A. Chemoluminescence generation and MTT dye reduction by polymorphonuclear leukocytes from periodontal disease patients. J. Periodont. Res., 29:109-112 1994

7. Haubek, D.; Poulsen, K.; Asikainen, S.; Kilian, M. Evidence for absence in northern Europe of especially virulent clonal types of Actinobacillus actinomycetemcomitans. J. Clin. Microbiol., 33:395401, 1995.

8. Hritz, M.; Fisher, E.; Demuth, D.R. Differential regulation of the leukotoxin operon in highly leukotoxic and minimally leukotoxic strains of Actinobacillus actinomycetemcomitans. Infect. Immun., 64:2724-2729, 1996

9. Kraig, E.; Dailey, T.; Kolodrubetz, D. Nucleotide sequence of the leukotoxin gene from Actinobacillus actinomycetemcomitans: homology to the alpha-hemolysin/leukotoxin gene family. Infect. Immun., 58:920-929,1990.

10. Lally, E.T.; Golub, E.E.; Kieba, I.R.; Taichman, N.S.; Decker, S ; Berthold, P.; Gibson, C.W. Structure and function of the $B$ and $D$ genes of the Actinobacillus actinomycetemcomitans leukotoxin complex. Microb. Pathog., 11:111-121, 1991.

11. Lowry, O.H.; Rosebrough, N.J.; Farr, A.L.; Randall, R.J. Protein measurement with the Folin phenol reagent. J. Biol. Chem., 193:265$75,1951$.

12. Mangan, D.F.; Taichman, N.S.; Lally, E.T.; Wahl, S.M. Lethal effects of Actinobacillus actinomycetemcomitans leukotoxin on human $\mathrm{T}$ lymphocytes. Infect. Immun., 59:3267-3272, 1991.

13. Mizoguchi, K.; Ohta, H.; Miyagi, A.; Kurihara, H.; Takashiba, S.; Kato, K.; Murayama, Y.; Fukus, K. The regulatory effect of fermentable sugar levels on the production of leukotoxin by Actinobacillus actinomycetemcomitans. FEMS Microbiol. Lett., 146:161-166, 1997.

14. Ohta, H.; Kokeguchi, S.; Fukui, K.; Kato, K. Leukotoxic activity in Actinobacillus (Haemophilus) actinomycetemcomitans isolated from periodontal disease patients. Microbiol. Immunol., 31:313-325, 1987.

15. Ohta, H.; Kato, K.; Kokeguchi, S.; Hara, H.; Fukui, K.; Murayama, Y. Nuclease-sensitive binding of an Actinobacillus actinomycetemcomitans leukotoxin to the bacterial cell surface. Infect. Immun., 59:4599$4605,1991$.

16. Ohta, H.; Hara, H.; Fukui, K.; Kurihara, H.; Murayama, Y.; Kato, K. Association of Actinobacillus actinomycetemcomitans leukotoxin with nucleic acids on the bacterial cell sufarce. Infect. Immun., 61:4878-4884, 1993

17. Ohta, H.; Miyagi, A.; Kato, K.; Fukui, K. The relationships between leukotoxin production, growth rate and the bicarbonate concentration in a toxin-production-variable strain of Actinobacillus actinomycetemcomitans. Microbiology, 142:963-970 1996.

18. Passos, S.A.; Syed, S.A.; Silva, J.Jr. Neutrophil chemiluminescence in response to Fusobacterium nucleatum. J. Periodontal. Res., 17:604-613, 1982.

19. Slots, J.; Reynolds, H.S.; Genco; R.J. Actinobacillus actinomycetemcomitans in human periodontal disease: a crosssectional microbiological investigation. Infect Immun., 29:10131020,1980

20. Spitznagel, J.Jr.; Kraig, E.; Kolodrubetz, D. Regulation of leukotoxin in leukotoxic and nonleukotoxic strains of Actinobacillus actinomycetemcomitans. Infect. Immun., 59:1394-1401, 1991

21. Spitznagel, J.Jr.; Kraig, E.; Kolodrubetz, D. The regulation of leukotoxin production in Actinobacillus actinomycetemcomitans strains JP2. Adv. Dent. Res., 9:48-54, 1995. 
22. Stevens, R.H.; Lillard, S.E.; Hawmmond, B.F. Purification and Biochemical Properties of a Bacteriocin from Actinobacillus actinomycetemcomitans. Infect. Immun., 55:692-697, 1987.

23. Taichman, N.S.; Dean, R.T.; Sanderson, C.J. Biochemical and morphological characterization of the killing of human monocytes by a leukotoxin derived from Actinobacillus actinomycetemcomitans. Infect. Immun., 28:258-268, 1980.

24. Taichman, N.S.; Simpson, D.L.; Sakurada, S.; Cranfield, M.; DiRienzo, J.; Slots J. Comparative studies on the biology of Actinobacillus actinomycetemcomitans leukotoxin in primates. Oral Microbiol. Immunol., 2:97-104, 1987.

25. Tsai, C.; Shenker, B.J; DiRienzo, J.S.; Malamud, D.; Taichman, N.S. Extraction and isolation of a leukotoxin from Actinobacillus actinomycetemcomitans with polymyxin B. Infect Immun., 43:700$705,1984$.

26. Tsai, C.C.; Taichman, N.S. Dynamics of infections by leukotoxic strains of Actinobacillus actinomycetemcomitans in juvenil periodontitis. J Clin. Periodontol., 11:330-331, 1986.

27. Winkelhoff, A.J.V.; Slots, J. Actinobacillus actinomycetemcomitans and Porphyromonas gingivalis in nonoral infections. Periodontology 2000, 20:122-135, 1999.

28. Wolfe, N.D.; Escalante, A.A.; Karesh, W.B.; Kilbourn, A.; Spielman, A.; Lal, A.A. Wild primate populations in emerging infectious disease research: the missing Link? Emerg. Infect. Dis., 4:149-158, 1998.

29. Zambon, J.J. Actinobacillus actinomycetemcomitans in human periodontal disease. J. Clin. Periodontol., 12:1-20, 1985. 